\title{
Total Synthesis of Agrocin 84 and Phosmidosine as Naturally Occurring Nucleotidic Antibiotics Having P-N Bond Linkages
}

\author{
Mitsuo Sekine*, Tomohisa Moriguchi, Takeshi Wada, and Kohji Seio \\ Department of Life Science, Tokyo Institute of Technology,
}

Received July 23, 2001

\begin{abstract}
This review deals with our recent studies of the synthesis of naturally occurring nucleic acid derivatives having P-N linkages. The total synthesis of a nucleotidic antibiotic, agrocin 84 (1), having two different types of unique phosphoramidate bonds is described in detail. Synthesis of this natural product remained unrealized for a long time after its discovery in 1974, but development of a new method for the construction of the $\mathrm{P}-\mathrm{N}$ bond led us to our final goal. Phosmidosine (2) is an antibiotic that has an antifungal activity and has a rare $O$-methylated phosphoramidate structure. This compound was also successfully synthesized by use of 5-(3,5-dinitrophenyl)-1 $\mathrm{H}$-tetrazole (DNPT) as the powerful activator of an $\mathrm{N}^{-}$ prolyl phosphorodiamidite derivative that was condensed with an 8-oxoadenosine derivative. Several related compounds were also synthesized. These phosmidosine derivatives were found to exhibit significant antitumor activities. In connection with these studies, the synthesis and biological properties of aminoacylamidoAMP derivatives having N-P bonds as stable analogues of aminoacyl-AMP are also described.
\end{abstract}

\section{Introduction}

Compared with a wide variety of natural products having phosphate ester linkages $(>\mathrm{P}(\mathrm{O})-\mathrm{OR})$, those containing phosphoramidate linkages $\left(>\mathrm{P}(\mathrm{O})-\mathrm{NR}^{1} \mathrm{R}^{2}\right)$ are rare in nature but have unique structures and intriguing biological properties. ${ }^{1}$ Phosphocreatine ${ }^{2}$ and phosphoarginine ${ }^{3}$ are well-known high-energy compounds. Phosphoramidon is a sugar-dipeptide conjugate, which specifically inhibits thermolysin and collagenase. ${ }^{4}$ Agrocin 84 (1) is a fraudulent adenine nucleotide bacteriocin that biologically controls a plant cancer, crown gall. ${ }^{5-9}$ Agrocin 84 has a characteristic structure in which the 1-hydroxyl group of glucofuranose is connected to the 6 -amino group of the adenine via a phosphoramidate bond. ${ }^{10}$ In addition, an $N$-acyl phosphoramidate linkage exists at the $5^{\prime}$-position.

Dinogunelline also has a similar $N$-acyl phosphoramidate linkage at the $5^{\prime}$-position of the adenosine moiety. ${ }^{11}$ Phosmidosine (2) was found as a new type of antibiotic having an antifungal activity by Uramoto and Isono et al. ${ }^{12}$ This compound also has an $\mathrm{N}$-acyl phosphoramidate linkage that connects 8 -oxoadenosine with L-proline. ${ }^{13}$

Although these naturally occurring phosphoramidate derivatives have been isolated and their structures have been

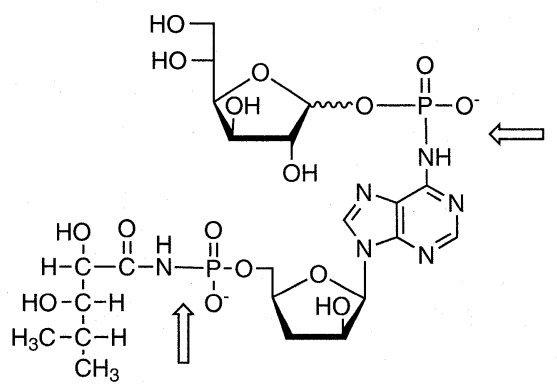

Agrocin 84 (1)

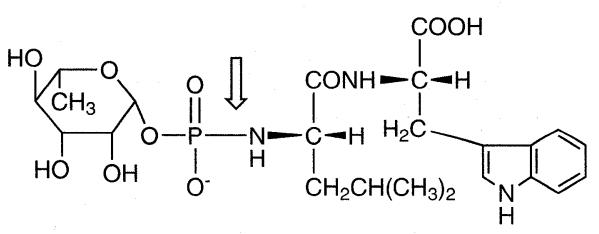

Phosphoramidon<smiles>C=C=C[C@H]1CCCN1C(=O)N[P+]([O])(=O)OC[C@H]1O[C@@H](n2c(=O)[nH]c3c(N)ncnc32)[C@H](O)[C@H]1O</smiles>

Phosmidosine (2)<smiles>C=COCC(O)COP(=O)(NC(=O)CC(N)=O)OC[C@H]1O[C@@H](n2cnc3c(N)ncnc32)[C@H](O)[C@H]1O</smiles>

Dinogunellin<smiles>C=COP(=O)(O)NC(=N)N(C)CC(=O)O</smiles>

Phosphocreatine<smiles>C=CCCCCCNC(=N)NP(=O)([O-])O</smiles>

Figure 1. Natural products containing $\mathrm{P}-\mathrm{N}$ bonds. 
determined, no successful synthesis of these compounds had been achieved until our first total synthesis of agrocin 84 was reported. ${ }^{14}$

In this review, we describe the basic property of the phosphoramidate linkage of $N$-phosphorylated nucleoside derivatives and our recent studies of the total synthesis of agrocin 84 , phosmidosine, and related compounds that have $\mathrm{P}-\mathrm{N}$ bonds.

\subsection{Reactivity of the Exo-amino Groups of Nucleoside Derivatives toward Phosphorylating Reagents}

Before going into the details of the synthesis of agrocin 84 , we summarize the basic chemical properties of $N$-phosphorylated nucleoside derivatives to understand such unique $\mathrm{P}-\mathrm{N}$ linkages involved in agrocin 84 . From the chemical point of view, the exo-amino groups of adenosine and cytidine have sufficient reactivity toward electrophiles such as acylating and phosphorylating reagents. Particularly, the cytidine base is so reactive that the selective $N$-modification can be achieved even without protection of other functional groups. ${ }^{15,16}$

Todd first reported the chemical $N$-phosphorylation of cytidine with phosphorylating reagents. ${ }^{16}$ Later, Letsinger found that the free exocyclic amino groups of deoxyadenosine and deoxycytidine were partially phosphitylated with activated phosphoramidite reagents in his original strategy of DNA synthesis without base protection. ${ }^{18,19}$ Hayakawa reported the synthesis of $N$-diethoxyphosphorylated deoxyadenosine derivatives via $6-N$-metalation with tBuMg$\mathrm{Cl}^{20}$ These results imply that such chemically reactive amino functions could be potential sites for biological phosphorylation. However, there are no examples of naturally occurring $N$-phosphorylated nucleosides except for agrocin 84 . Why aren't simpler $N$-phosphorylated nucleosides found from biological sources? Is it impossible to phosphorylate the amino group of adenosine, cytidine, or guanosine via an enzymatic process? It is still unknown whether the N-P bond of $N$-phosphorylated ribonucleosides is so unstable in living cells that the presence of such $N$-phosphorylated species cannot be detected even if they can be produced enzymatically. In general, the inherent instability of the $\mathrm{P}-\mathrm{N}$ bond containing phosphoramidate derivatives has been noted. ${ }^{21}$

\subsection{Chemical and Biological Properties of $\mathrm{N}$-Phosphory- lated Nucleoside Derivatives ${ }^{22}$}

To obtain an answer to the above questions and unveil the unknown nature of $\mathrm{N}$-phosphorylated nucleosides, we decided to synthesize $N$-phosphorylated cytidine (6:4-N-CMP), adenosine (7:6-N-AMP), and guanosine (8:2-N-GMP) (In this review, we call these $N$-phosphorylated ribonucleotides " $N$-nucleotides"). In 1979, Kerr first synthesized 7 as a reference material for the structural determination of agrocin 84 , but no details of this synthetic method were described. ${ }^{10 \mathrm{~b}}$ In 1994, we confirmed these $N$-nucleotides 6-8 could be easily obtained as sufficiently stable disodium salts by phosphitylation of appropriately $2^{\prime}, 3^{\prime}, 5^{\prime}-O$-protected ribonucleoside derivatives 3 with a phosphitylating reagent $\mathbf{4}$ followed by treatment of the fully protected $N$-phosphorylated derivatives 5 with ammonia, as shown in Scheme 1.22

The chemical properties of these $N$-phosphorylated ribonucleoside derivatives are summarized in Table 1.

The stability of the three $N$-nucleotides under the acidic conditions of $0.1 \mathrm{M} \mathrm{HCl}$ at $25{ }^{\circ} \mathrm{C}$ decreases in the following
Scheme 1

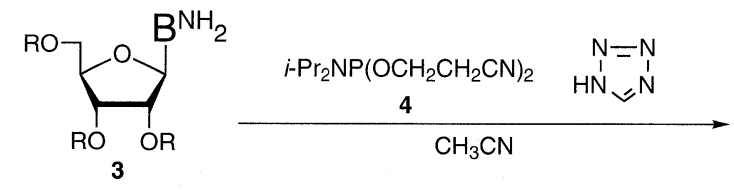

$$
\begin{aligned}
& \text { a: } B^{\mathrm{NH}_{2}}=\text { Cyt, } \mathrm{R}=\mathrm{Bz} \\
& \text { b: } \mathrm{B}^{\mathrm{NH}_{2}}=\mathrm{Ade}, \mathrm{R}=\mathrm{Bz} \\
& \text { c: } \mathrm{B}^{\mathrm{NH}_{2}}=\text { Gua, } \mathrm{R}=\mathrm{Bz}
\end{aligned}
$$
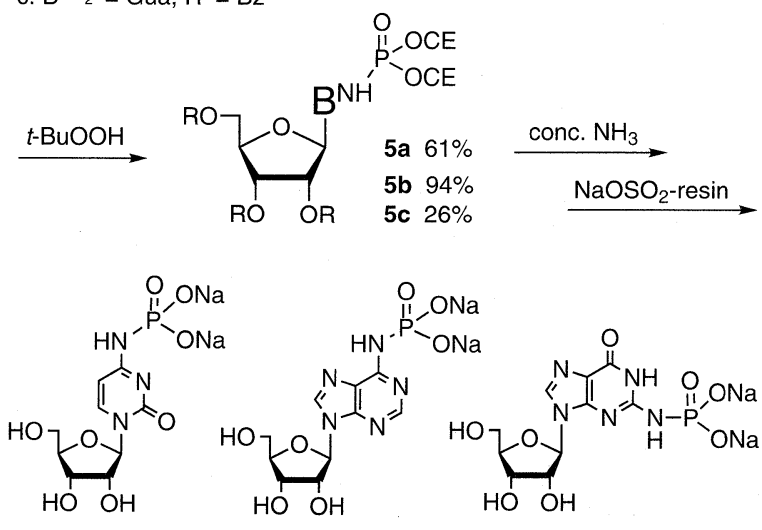

6: $4-N$-CMP $76 \% \quad$ 7: 6-N-AMP $91 \% \quad$ 8: 2 - $N$-GMP $99 \%$

Table 1. Stability of $N$-nucleotides 6-8 under acidic and basic conditions

\begin{tabular}{cccccccc}
\hline & \multicolumn{2}{c}{ 6: 4-N-CMP } & \multicolumn{2}{c}{ 7: 6-N-AMP } & \multicolumn{2}{c}{ 8: 2- N-GMP } \\
& $t_{1 / 2}$ & $t_{\text {comp }}$ & $t_{1 / 2}$ & $t_{\text {comp }}$ & $t_{1 / 2}$ & $t_{\text {comp }}$ \\
\hline $0.1 \mathrm{M} \mathrm{HCl}$ & $8 \mathrm{~h}$ & $3 \mathrm{~d}$ & $4 \mathrm{~h}$ & $24 \mathrm{~h}$ & $5 \mathrm{~h}$ & $30 \mathrm{~h}$ \\
$80 \% \mathrm{AcOH}$ & $4 \mathrm{~d}$ & - & $24 \mathrm{~h}$ & $4 \mathrm{~d}$ & $7 \mathrm{~h}$ & $60 \mathrm{~h}$ \\
$0.1 \mathrm{M} \mathrm{NaOH}$ & stable & & stable & & stable \\
conc. $\mathrm{NH}_{3}$ & stable & & stable & & stable \\
\hline
\end{tabular}

order: $4-N-\mathrm{CMP}>2-N-\mathrm{GMP}>6-N$-AMP. In $80 \%$ acetic acid, the order changes to $4-N-\mathrm{CMP}>6-N-\mathrm{AMP}>2-N-$ GMP. Under such acidic conditions, the $N$-nucleotides were hydrolyzed to inorganic phosphoric acid and the parent nucleosides. Contrary to these facts, these $N$-nucleotides were found to be stable under basic conditions of $0.1 \mathrm{M} \mathrm{NaOH}$ or conc. ammonia. If nature really creates these "new nucleotides" in living cells, they should be discovered. However, this possibility has not been reported to date. The thermal stability of 4-N-CMP, 6-N-AMP, and 2-N-GMP is shown in Table 2.

Table 2. The thermal stability of $N$-nucleotides $6-8$ at $70{ }^{\circ} \mathrm{C}$ and $90{ }^{\circ} \mathrm{C}$

\begin{tabular}{ccccccc}
\hline \multirow{2}{*}{ conditions } & $\begin{array}{c}\text { 6: } \\
\mathrm{t}_{1 / 2}\end{array}$ & $\mathrm{t}_{\mathrm{comp}}$ & $\mathrm{t}_{1 / 2}$ & $\mathrm{t}_{\mathrm{comp}}$ & $\mathrm{t}_{1 / 2}$ & $\mathrm{t}_{\mathrm{comp}}$ \\
\hline $90^{\circ} \mathrm{C}$ & - & $<10 \mathrm{~min}$ & - & $<10 \mathrm{~min}$ & - & $<10 \mathrm{~min}$ \\
$70^{\circ} \mathrm{C}$ & - & $60 \mathrm{~min}$ & - & $60 \mathrm{~min}$ & - & $60 \mathrm{~min}$ \\
$k\left(\times 10^{4} \mathrm{~s}^{-1}\right)$ & $9.8^{\mathrm{a}}$ & $9.8^{\mathrm{a}}$ & $11^{\mathrm{a}}$ \\
\hline
\end{tabular}

a $70^{\circ} \mathrm{C}$

Upon heating them, dephosphorylation of 2-N-GMP occurred slightly faster than the others. At $90{ }^{\circ} \mathrm{C}$, the phosphoryl group was completely eliminated from these $N$-nucleotides within $10 \mathrm{~min}$. The mechanism of the dephosphorylation might involve generation of a metaphosphate species, as depicted in Scheme 2. The dephosphorylation of $N$-nucle- 
otides is very fast compared with that of $5^{\prime}$-nucleotides. ${ }^{23}$ For example, the $5^{\prime}$-terminal phosphate group of $(\mathrm{pT})_{10}$ was eliminated to a degree of $50 \%$ by heating at $90{ }^{\circ} \mathrm{C}$ for $24 \mathrm{~h}$. The internucleotidic phosphodiester linkages were rather stable under these conditions. Therefore, these results suggest that nature selected only stable linkages at the earlier stage of birth of life in a manner where essentially thermally unstable $N$-nucleotides were excluded as biological substrates for the preservation of life.

Scheme 2

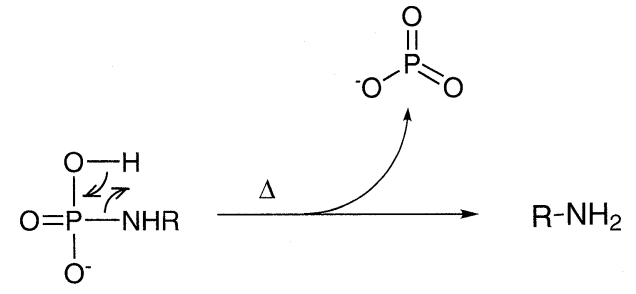

On the other hand, the thermal stability of the diethyl ester derivatives of $4-N-\mathrm{CMP}$ and $6-N-\mathrm{AMP}$ increased 54 and 82 times more than that of $4-N-\mathrm{CMP}$ and $6-N-\mathrm{AMP}$, respectively. ${ }^{22}$ These $N$-nucleotides and their diethyl esters proved to exhibit neither antiviral activity against HIV nor mutagenesis activity, except that $2-N-\mathrm{GMP}$ has a slight anti-HIV activity $\left(\mathrm{EC}_{50}=352 \mu \mathrm{g} / \mathrm{ml}, \mathrm{CC}_{50}=>500 \mu \mathrm{g} / \mathrm{ml}\right){ }^{24}$

\subsection{Chemical and Biological Properties of Agrocin 84}

Agrocin 84 (1) is produced by Agrobacterium tumefaciens $\mathrm{K} 84^{5}$ harboring a tumor-inducing (Ti) plasmid and inhibits thymidine uptake in this strain so that the DNA synthesis is regulated. Studies of its biosynthesis ${ }^{25}$ and sensitivity ${ }^{26}$ have also been reported. The $5^{\prime}$-phosphoramidate substituent is essential for the biological activity of agrocin 84 , while the $6-N-[$ (glucofuranosyloxy)phosphoryl]adenine moiety is a site for binding to a protein responsible for the strain-specific uptake of agrocin $84 .^{27,28}$

Kerr et al. reported several properties of agrocin 84 under acidic and basic conditions: ${ }^{10}$ Treatment of agrocin 84 with 1 $\mathrm{M}$ ammonia gave the product 9 lacking the pentanamide residue at the $5^{\prime}$-position. Heating of agrocin 84 at $110{ }^{\circ} \mathrm{C}$ at $\mathrm{pH} 7$ resulted in formation of the product $\mathbf{1 0}$ dephosphory- lated at the 6-position, which shows one-fiftieth of the biological activity of agrocin 84 . When the resulting dephosphorylated product 10 was treated with $0.1 \mathrm{M} \mathrm{HCl}$, phosphoryl migration occurred to give the regioisomer 11, which shows no biological activity.

\subsection{Synthesis of 6-N-Glycosyloxyphosphorylated Adeno- sine Derivatives as Partial Structures of Agrocin $84^{29}$}

In the early studies on the synthesis of agrocin 84, Robins and his co-workers ${ }^{30}$ reported the synthesis of a nucleosidesugar conjugate, $6-\mathrm{N}-[(1-\mathrm{O}$-methylglucopyranos-6-yloxy) phosphoryl]adenosine (14), which has an $\mathrm{O}\left(6^{\prime \prime}\right)-\mathrm{P}-\mathrm{N}(6)$ linkage, by reaction of a glucose-6-O-phosphite derivative $\mathbf{1 2}$ and 6-azidoapurine derivative $\mathbf{1 3}$ and also described the great difficulty in forming the $\mathrm{O}\left(1^{\prime \prime}\right)-\mathrm{P}-\mathrm{N}(6)$ bond required for the synthesis of agrocin 84 in a similar strategy.

The two phosphoramidate bonds involved in agrocin 84 had not been synthesized until van Boom's paper appeared in 1997. ${ }^{31 a}$ His group synthesized the partial mimic structure $\mathbf{1 8}$ of agrocin 84 involving the $N$-acyl $5^{\prime}$-phosphoramidate linkage by use of two kinds of phosphitylations of compound $\mathbf{1 5}$ with the cyclopentyl and propanamide phosphoramidite reagents $\mathbf{1 6}$ and 17, as shown in Scheme 4. In their synthesis, the upper site of agrocin 84 was replaced with a simpler cyclopentyloxyl moiety. This is due to the difficulty in constructing the $\mathrm{O}-\mathrm{P}-\mathrm{N}$ bond, which is generally considered to be extremely unstable. ${ }^{21}$ The stereoselective introduction of either an unprotected or protected phosphoryl group into the anomeric center of glucofuranose is particularly difficult because such a 1-- $O$-phosphate functionality is also known to be very labile. ${ }^{32}$ Van Boom also reported the half molecule $\mathbf{2 1}$ of agrocin 84 by using phosphoramidite coupling between an $N$-phosphitylated pentanamide derivative 19 and $3^{\prime}$-deoxy$2^{\prime}-O$-acetylarabinoadenosine (20).

With these precedents in mind, we started the synthesis of a genuine part of agrocin $84,6-N-[(\beta-D-$ glucofuranosyloxy $)$ phosphoryl]adenosine (32) and its related compound, 6-N$\left[\left(\beta\right.\right.$-D-ribofuranosyloxy)phosphoryl]adenosine (28) ${ }^{29}$ The successful synthesis of $\mathbf{2 8}$ was achieved, as shown in Scheme 5. Reaction of 2,3,5-tri-O-acetylrifuranose 22 with 2-trimethylsilylethyl $N, N, N^{\prime}, N^{\prime}$-tetraisopropylphosphoramidite (23) in the presence of diisopropylammonium tetrazolide (24) gave

Scheme 3

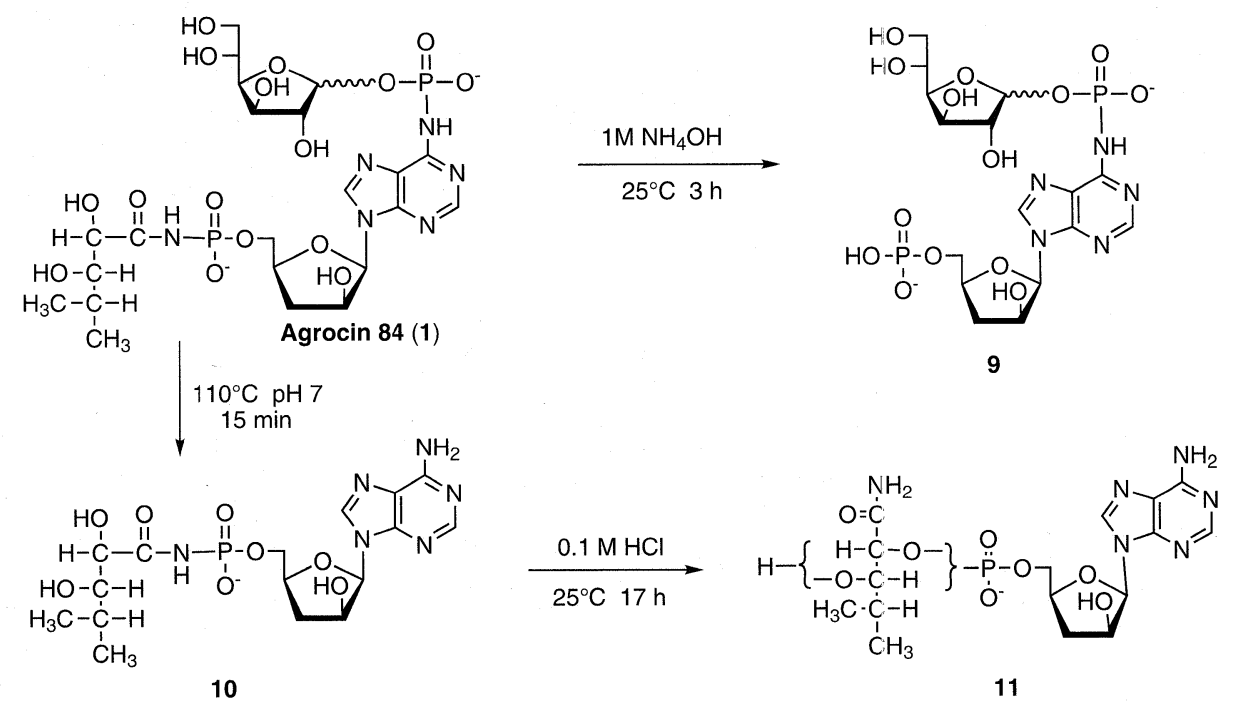


the 1-O-phosphoramidite derivative 25 . The $1 H$-tetrazolemediated condensation of 25 with $2^{\prime}, 3^{\prime}, 5^{\prime}$-tri- $O$-benzoyl adenosine (3b) gave the coupling product $\mathbf{2 6}$. However, this product was found to be unstable even during column chromatography. To avoid this inherent instability of the $O, O$ phosphoramidate diester, the 2-trimethylsilylethyl (TSE) group $^{33}$ was removed by treatment with TBAF. Consequently, the resulting $O$-phosphoramidate monoester 27 was found to be stable enough to be purified. When the 2-cyanoethyl group was employed, simultaneous partial deacylation occurred at other sites upon removal of the cyanoethyl group by $\mathrm{DBU}$ and thereby hampered the isolation of $\mathbf{2 7}$ from the complex mixture involving such decyanoethylated products.
Full deblocking of $\mathbf{2 7}$ with ammonia gave the desired product $\mathbf{2 8}$ in $69 \%$ yield. It was found that only one stereoisomer having $\beta$-configuration at the $\mathrm{Cl}^{\prime \prime}$ anomeric center could be obtained. It is likely that the $\alpha$-isomer decomposed with formation of ribofuranose 1,2-cyclic phosphate during the deprotection.

The real partial structure 32 of agrocin 84 was likewise obtained, as shown in Scheme 6. Reaction of a sugar phosphoramidite derivative $\mathbf{2 9}$ with $\mathbf{3 b}$ gave the coupling product 30. Similar selective removal of the TSE group gave the dissociated product $\mathbf{3 1}$, which in turn was converted to 32 . In this case, only the $\beta$-isomer $\mathbf{3 2}$ was also obtained at the last stage. The configuration of $\mathbf{2 8}$ and $\mathbf{3 2}$ was determined by ${ }^{13} \mathrm{C}$

Scheme 4
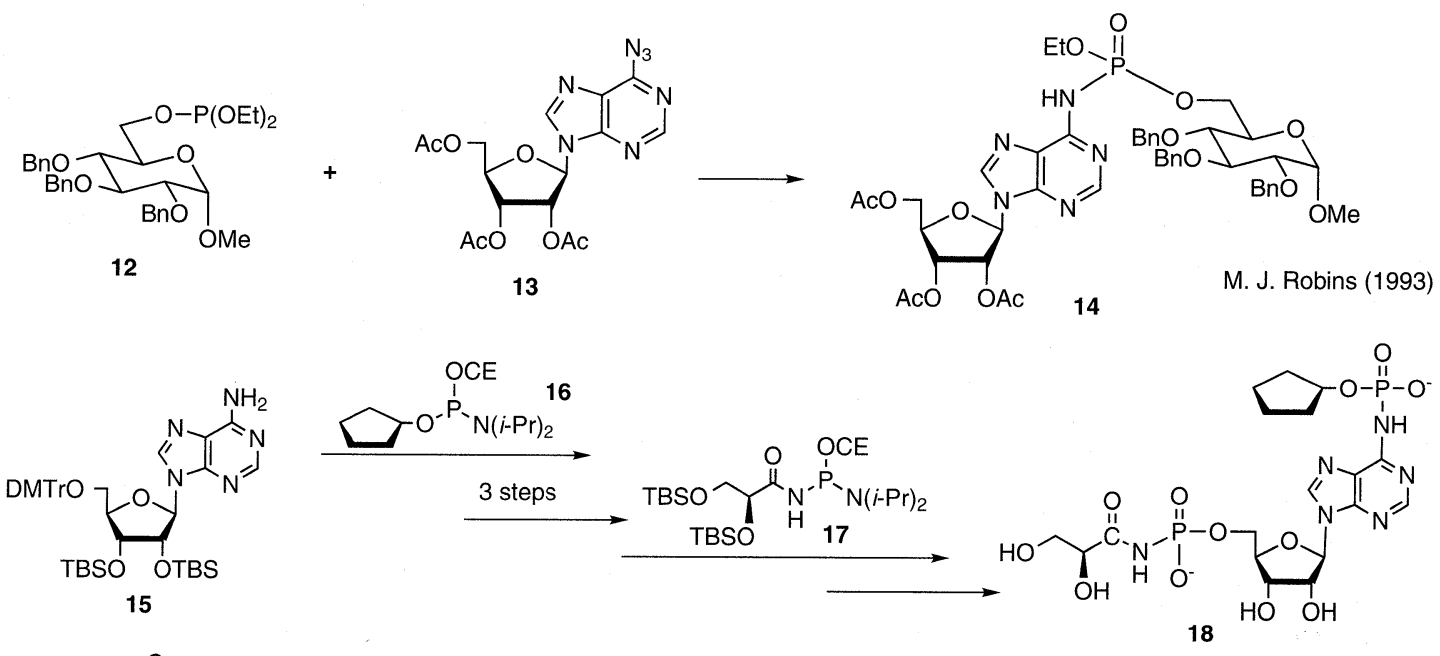<smiles>CC(C)CCC(=O)O</smiles>

19

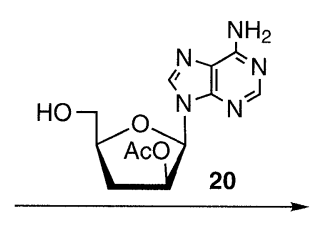<smiles>CC(C)[C@H](O)[C@H](O)C(=O)NP(=O)([O-])OCC1C[C@@H]2O[C@H]1O[C@@H]2n1cnc2c(N)ncnc21</smiles>

21
J. H. van Boom (1998)

Scheme 5

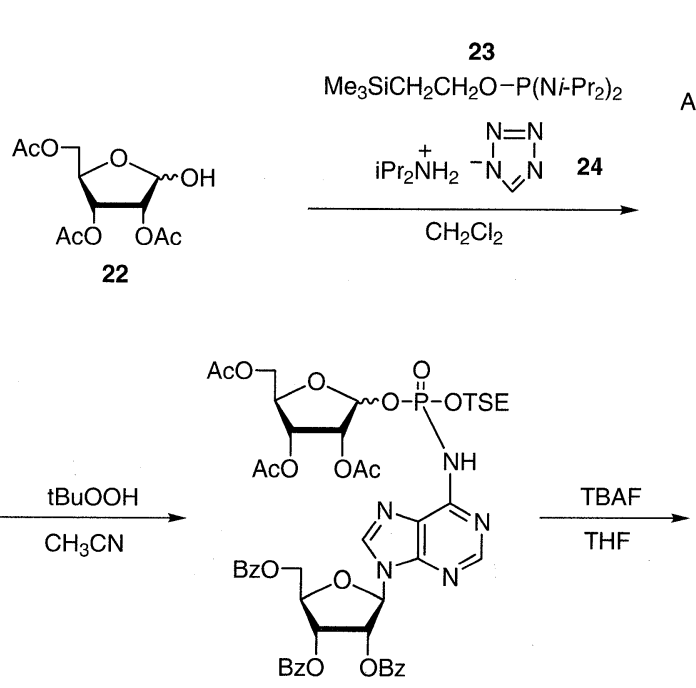

26

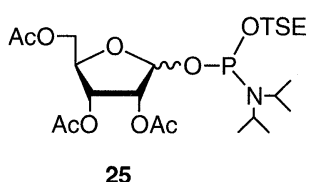

25

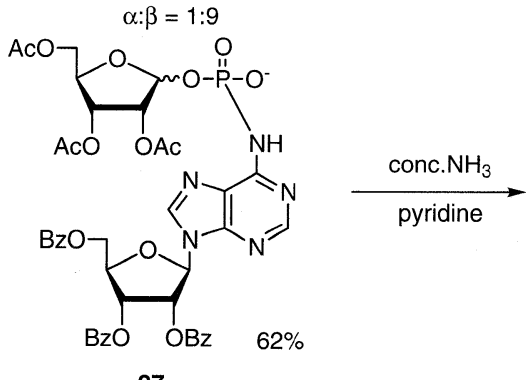

27

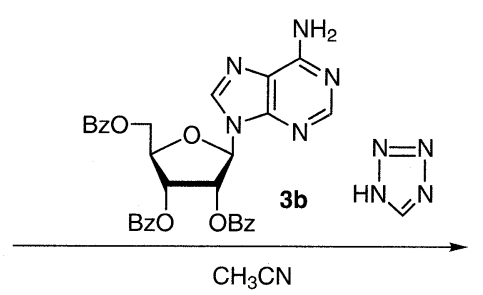

28 


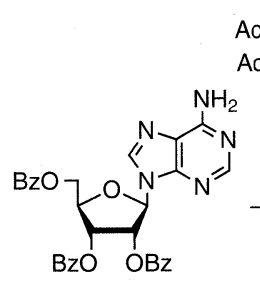

3b
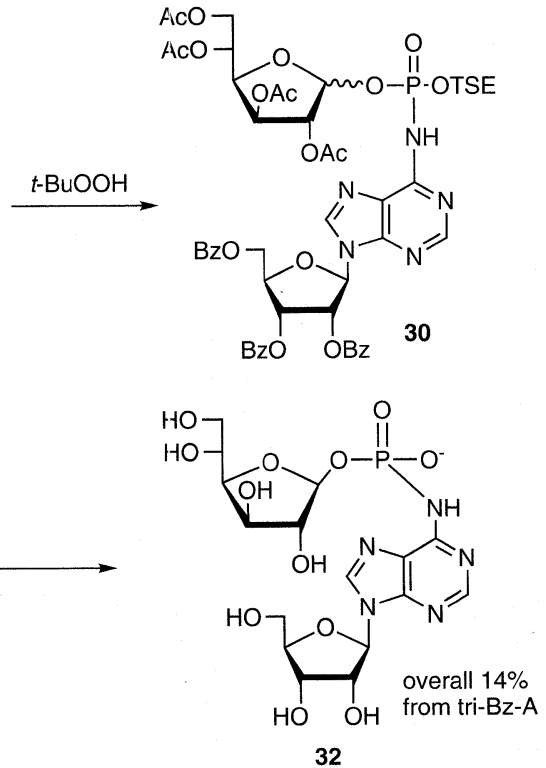

NMR.

\subsection{Hydrolytic Properties of $\mathbf{2 8}$ and $\mathbf{3 2}{ }^{29}$}

Sugar-nucleotide conjugate $\mathbf{2 8}$ and $\mathbf{3 2}$ were stable under neutral conditions such as $0.1 \mathrm{M} \mathrm{NH}_{4} \mathrm{OAc}$ but decomposed under acidic and basic conditions via unique hydrolytic processes. Upon treatment with $0.1 \mathrm{M} \mathrm{HCl}$, the $\mathrm{Cl}^{\prime \prime}-\mathrm{O}$ bonds of these compounds are predominantly cleaved over the $\mathrm{P}-\mathrm{N}$ bond to give adenosine (33). Contrary to these facts, basic treatment of these compounds gave 6-N-AMP. This hydrolysis pattern implies that strong bases such as the hydroxide ion abstracted the acidic proton of the $\mathrm{P}(\mathrm{O})-\mathrm{NH}$ group so that the $\mathrm{P}-\mathrm{O}$ bond cleavage occurred via formation of an azamethaphosphate derivative $\mathbf{3 5}$ from the dissociated intermediate 34, as shown in Scheme 7. The conjugates $\mathbf{2 8}$ and $\mathbf{3 2}$ are also thermally unstable. Upon heating $\mathbf{2 8}$ and $\mathbf{3 2}$ at $90{ }^{\circ} \mathrm{C}$ in $0.1 \mathrm{M} \mathrm{NH}_{4} \mathrm{OAc}$, adenosine is formed as the sole UV absorbing product after $35 \mathrm{~h}$ and $15 \mathrm{~h}$, respectively. The difference in decomposition rate between $\mathbf{2 8}$ and $\mathbf{3 2}$ can be explained in terms of the neighboring group participation of the $3-\mathrm{OH}$ group via the pentavalent intermediate $\mathbf{3 6}$, especially in the case of 32, as shown in Scheme 7.

\section{Scheme 7}

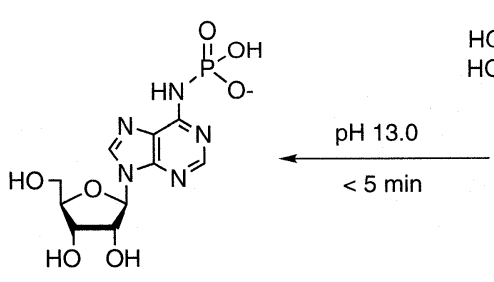

7: 6-N-AMP

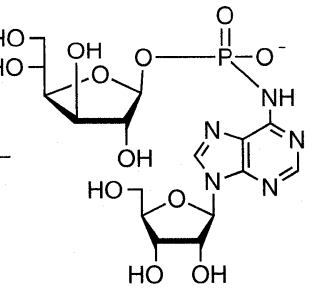

32

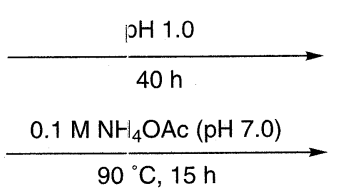

$90{ }^{\circ} \mathrm{C}, 15 \mathrm{~h}$

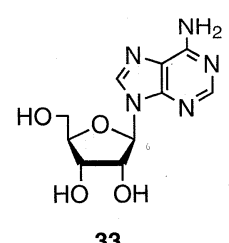

33

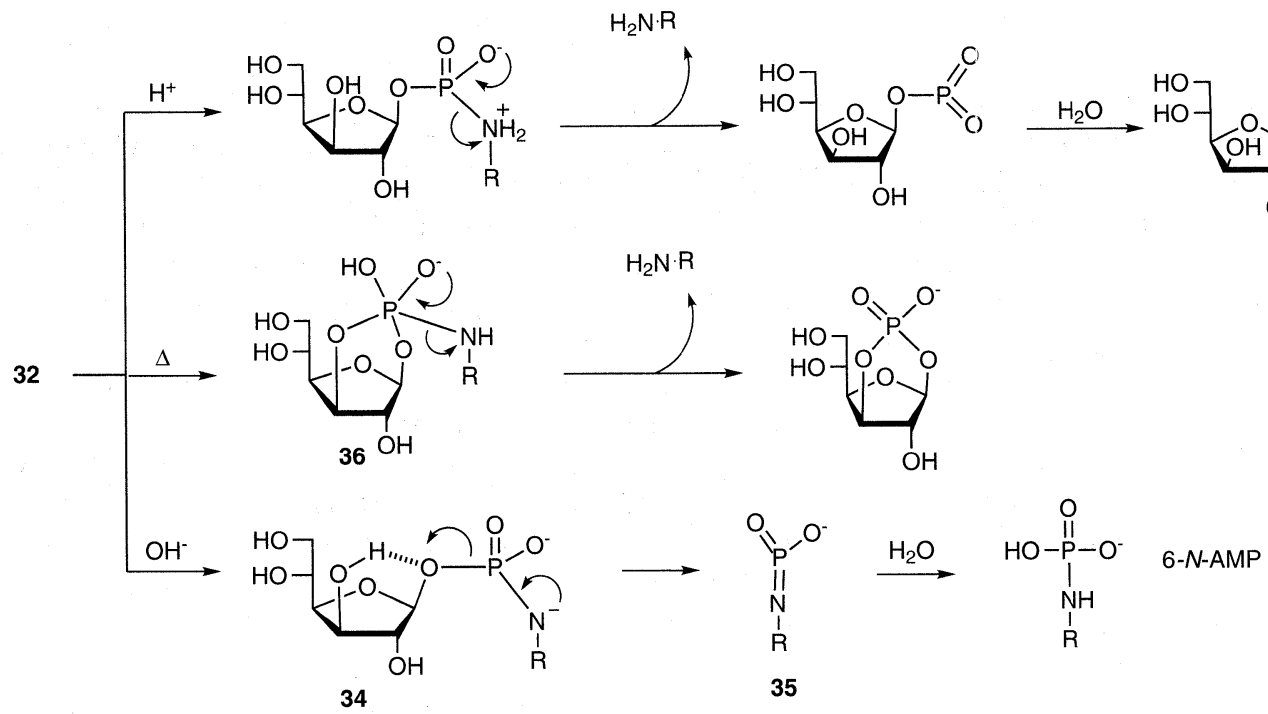



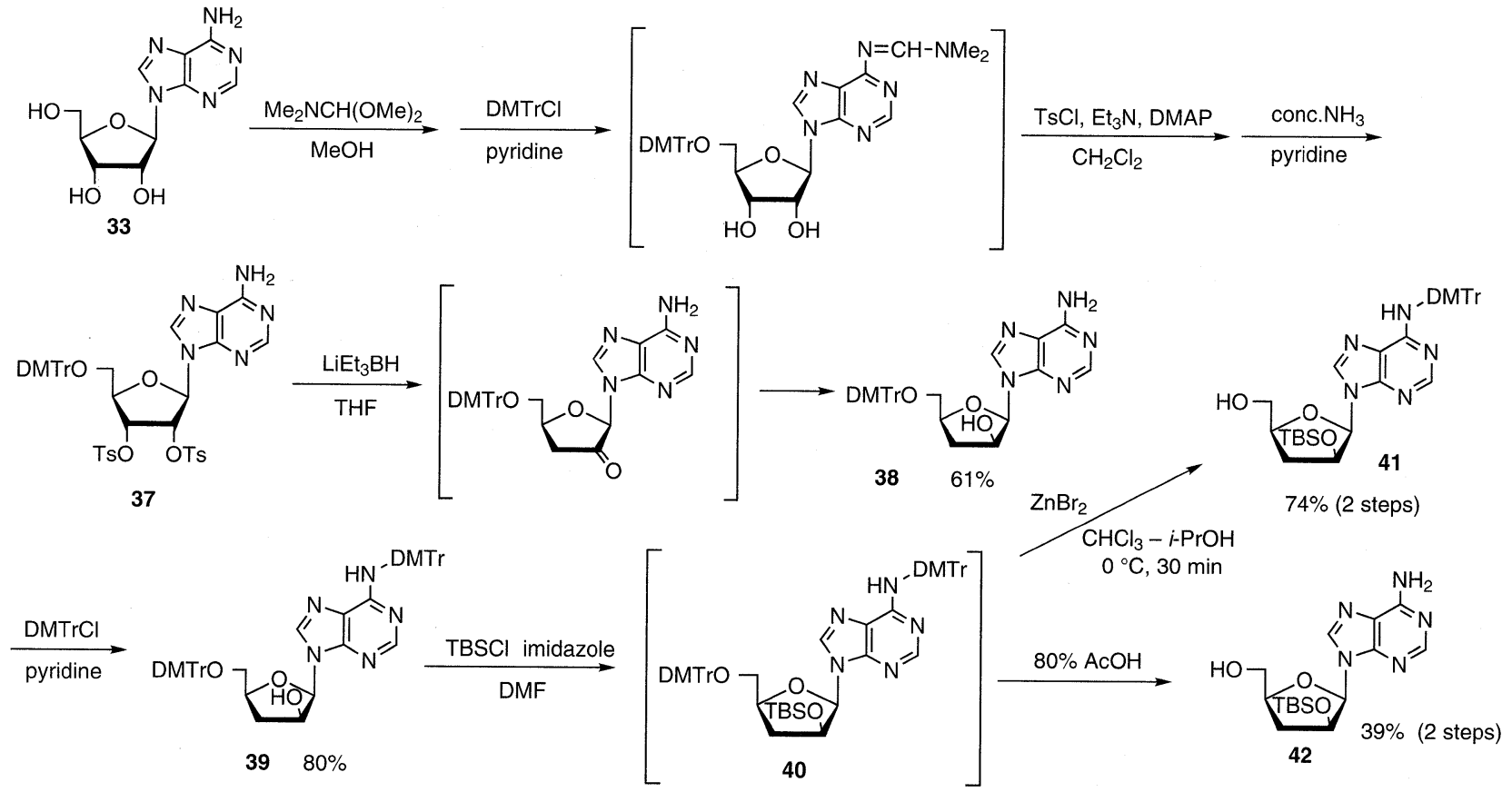

\subsection{Synthesis of 9-( $3^{\prime}-$ Deoxy- $\beta$-D-threo-pentofuranosyl $)$} denine as Core Nucleoside

A core nucleoside, 9-(3'-deoxy- $\beta$-D-threo-pentofuranosyl) adenine, required for the synthesis of agrocin 84 has been reported by several research groups. ${ }^{34}$ However, these methods involved multi-step reactions. In our studies, two key intermediates, i.e., 9-( $3^{\prime}-\operatorname{deoxy}-\beta$-D-threo-pentofuranosyl) adenine derivatives $\mathbf{4 1}$ and $\mathbf{4 2}$, required for construction of the left-half of agrocin 84 were synthesized conveniently by several-step reactions from adenosine, as shown in Scheme 8 . $5^{\prime}-O-\left(4,4^{\prime}-\right.$ Dimethoxytrityl)-2, 3'-di-O-tosyladenosine (37) was obtained by transient protection of $\mathbf{3 3}$ with an amidinetype group followed by successive treatments with $\mathrm{DMTrCl}$, tosyl chrolide and ammonia. Reduction of $\mathbf{3 7}$ with $\mathrm{LiEt}_{3} \mathrm{BH}^{34 \mathrm{c}, \mathrm{g}}$ gave the $5^{\prime}-O$-protected $9-\left(3^{\prime}-\right.$ deoxy- $\beta-\mathrm{D}-$ threo-pentofuranosyl)adenine derivative $38 .{ }^{35}$ Compound 38 was converted to $6-N, 5^{\prime}-O$-bis $\left(4,4^{\prime}\right.$-dimethoxytrityl)adenosine derivative 39. The $2^{\prime}-O$-protected derivative 40, in situ generated from 39, was selectively detritylated by $\mathrm{ZnBr}_{2}$ in $\mathrm{CHCl}_{3}-\mathrm{iPrOH}^{36}$ to give the $2^{\prime}-O, 6-N$-protected product $\mathbf{4 1}$ in good yield. Treatment of $\mathbf{4 0}$ with $80 \% \mathrm{AcOH}$ gave the $2^{\prime}-O$-masked product $\mathbf{4 2}$.

\subsection{Synthesis of Pentanamide Derivatives}

Another left-side component of agrocin 84 is $(2 S, 3 R)-2,3-$ dihydroxy-4-methylpentanamide (45). 2-Methylpropanal was converted to the trans $-\alpha, \beta$-unsaturated ester 43 , which in turn was allowed to react with $\mathrm{AD}-\mathrm{mix}-\beta^{31 \mathrm{~b}}$ to give the diol 44 in a stereo-controlled manner, as shown in Scheme 9. Ammonolysis of $\mathbf{4 4}$ gave the amide $\mathbf{4 5}$. The methoxymethylenation of $\mathbf{4 5}$ gave the protected amide $\mathbf{4 6}$.

There are two possible ways ${ }^{37}$ to construct the $N$-acyl phosphoramidate linkages for the synthesis of agrocin 84 . One is the activation of a phosphoramidite reagent having an acylamide structure. The other involves the reaction of a nucleoside phosphoramidite reagent with an acylamide derivative. Although we examined the two possibilities, we finally chose the former strategy.
Scheme 9<smiles>CCOC(=O)C=CC(C)C</smiles><smiles>CCOC(=O)[C@H](O)[C@@H](O)[C@H](C)C(C)C</smiles><smiles>CCN[P+](=O)OCCC#N</smiles>

Therefore, the $N, N$-phosphorodiamidite derivative $\mathbf{4 8}$ was synthesized by phosphitylation of $\mathbf{4 6}$ with a chlorophosphite reagent 47.

\subsection{Synthesis of Glucofuranose- $O$-phosphoramidte Derivative}

In this study, to facilitate the isolation of intermediates at a later stage of the total synthesis, we employed a stable benzyl group for all the hydroxyl groups of glucofranose derivatives. From 1,2-O-isopropylideneglucofuranose 49, 2, 3, 5, 6-tetra$O$-benzylglucofuranose $\mathbf{5 0}$ was obtained by a 6 -step reaction. The usual phosphitylation of $\mathbf{5 0}$ gave the phosphoramidite intermediate $\mathbf{5 1 .}$

\subsection{Coupling of $\mathbf{4 2}$ with $\mathbf{4 8}$}

At the initial stage of this work, we tried to use compound 41 for condensation with $\mathbf{4 8}$ but this strategy required the selective detritylation prior to the second condensation with 51. Later, we found that the $O$-selective phosphitylation of the $N$-free 42 with 48 could be carried out by use of 1-methyl- 
Scheme 10
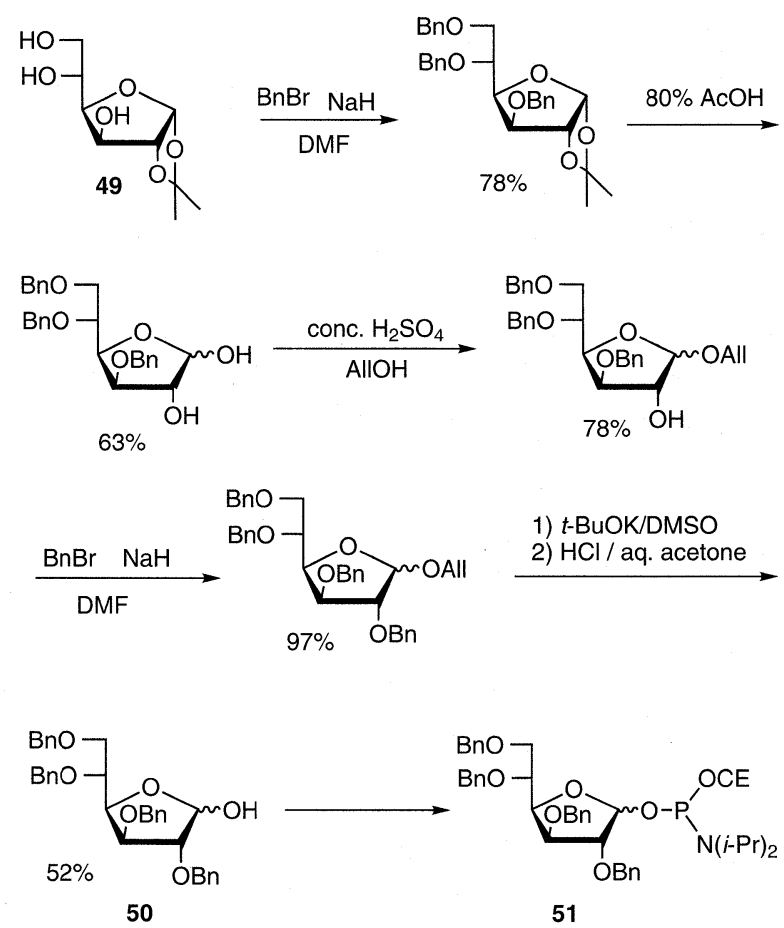

2-mercaptotetrazole, as demonstrated by van Boom. ${ }^{31 \mathrm{~b}}$ The phosphoramidite coupling gave the product 52. This reaction proceeded selectively without protection of the exo amino group of the adenine moiety. The second condensation of $\mathbf{5 2}$ with 51 was performed in the presence of $1 H$-tetrazole. This reaction gave the phosphorylated product. Successive in situ treatments of the coupling product with $\mathrm{K}_{2} \mathrm{CO}_{3}$ and TBAF gave the dissociated product $\mathbf{5 3}$. Treatment of $\mathbf{5 3}$ with $80 \%$ acetic acid gave the partially blocked agrocin 84 (54). Hydrogenation of this compound gave agrocin $84(1 \beta)$ in ca. $20 \%$ yield. This final product had only the $\beta$-configuration.

\subsection{Synthesis of Aminoacyl Adenylate Analogues ${ }^{38}$}

Aminoacyl adenylates (55: aa-AMP) are well known to play an important role in aminoacyl transfer to tRNA and are extremely unstable even under neutral conditions. ${ }^{39} \mathrm{We}$ first started to synthesize chemically stable aminoacyl adenylate analogues (56: aminoacylamido-AMP) for studies of $\mathrm{X}$-ray analysis of aminoacyl adenylate-synthetase complexes to clarify the mechanism of aminoacylation from aminoacyl adenylates to the $3^{\prime}$-terminal CCA of tRNA. As stable mimics, we designed $N$-aminoacyl phosphoramidate derivatives of aa-AMP replacing the oxygen between the phosphoryl and acyl groups with the $\mathrm{NH}$ function. The previous $\mathrm{X}$-ray data of the histidine-synthetase complex suggested that this replacement does not affect the total hydrogen bond network structure around His-AMP in the crystal structure. ${ }^{40}$ There are several precedents of aa-AMP analogues 57-60, as shown in Figure $2 .^{41-42}$

They are uniformly far from the original structure or lack a dissociate anion. Our analogues look like the best models in both structural and electronic aspects.

As a previous method for the synthesis of $N$-acyl phosphoramidate derivatives, Grandas ${ }^{37}$ reported $1 \mathrm{H}$-tetrazoleactivated $\mathrm{P}-\mathrm{N}$ bond formation between a thymidine 3 '-phosphoramite derivative and acylamides. We optimized the conditions in this type of reaction using phenylacetamide (61) with a thymidine $5^{\prime}-O$-phosphoramidite derivative $\mathbf{6 2}$ giving rise to the $N$-acyl phosphoramidte derivatives $\mathbf{6 3}$ using various activators, as shown in Scheme 12 . As the result, 5- $(3,5-$ dinitrophenyl)-1 $H$-tetrazole (DNPT) ${ }^{45}$ was found to be effective, as shown in Table 3. The usual activator, $1 \mathrm{H}$-tetrazole, ${ }^{46}$ showed low activity with $17 \%$ yield of the product. DNPT could be used for coupling between $\mathbf{6 1}$ and an adenosine $5^{\prime}-O$-phosphoranidite derivative $\mathbf{6 4}$ having the TSE group to give the product $\mathbf{6 5}$ in high yield.

A variety of amino acid amide derivatives $\mathbf{6 6}$ protected with tris $\left(4,4^{\prime}, 4^{\prime \prime} \text {-benzoyloxy)trityl (TBTr }\right)^{47}$ were synthesized. The TBTr group can be easily detected by its trityl cation upon TLC and facilitate isolation of products because of its high lipophilicity. This trityl group can be removed under mild basic conditions such as ammonia. The $\mathrm{P}-\mathrm{N}$ bond formation of the $N$-TBTr-amide derivatives 66 with the adenosine $5^{\prime}-O$-phosphoramidite derivative 64 was carried out in

Scheme 11
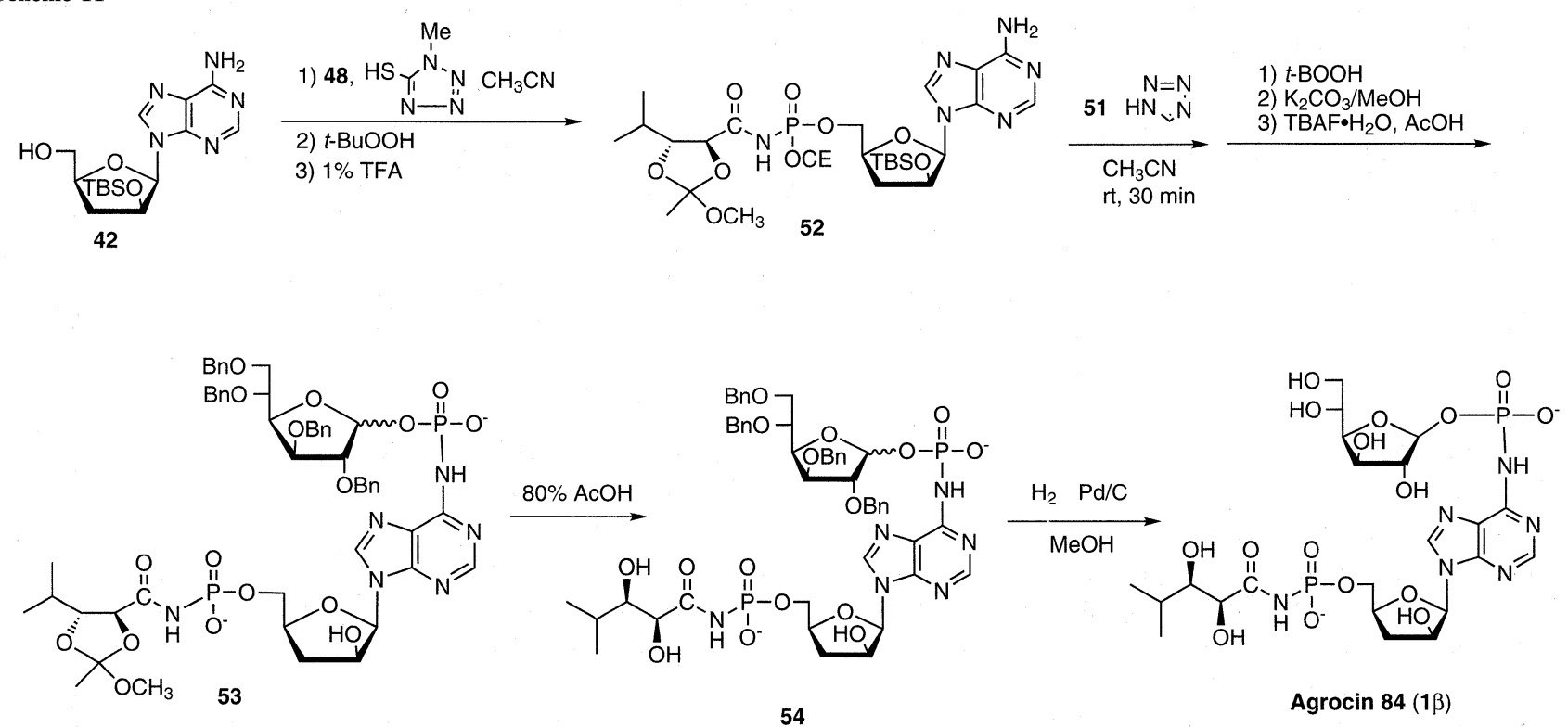


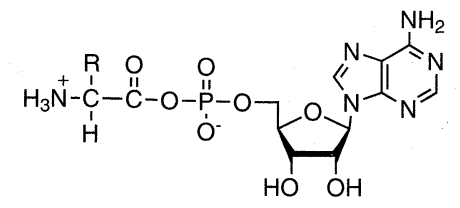

Aminoacyl adenylate (aa-AMP)

55

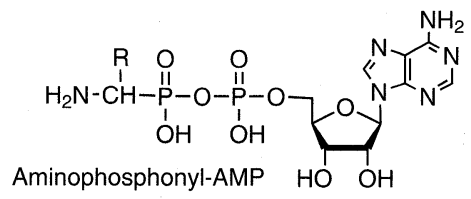

58

A. I. Biryukov (1978)

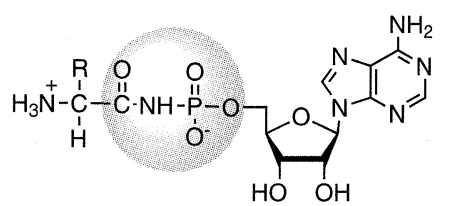

Aminoacylamido-AMP

56

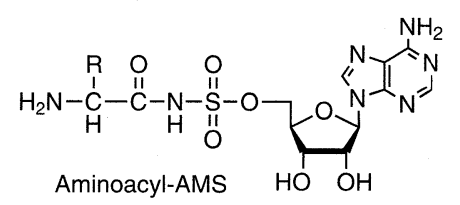

59 H. Ueda (1991)
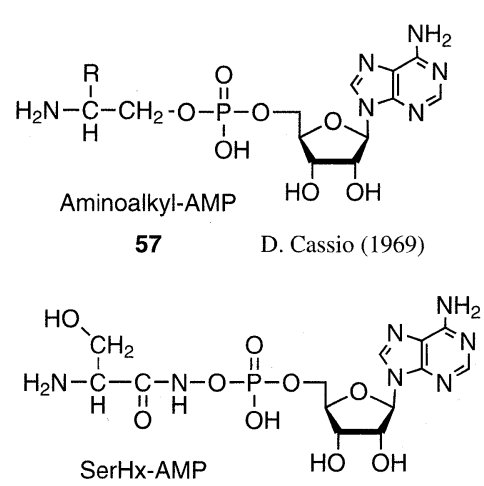

60 V. Biou (1994)

Figure 2. Aminoacyl-adenylate analogs as stable compounds.

Scheme 12
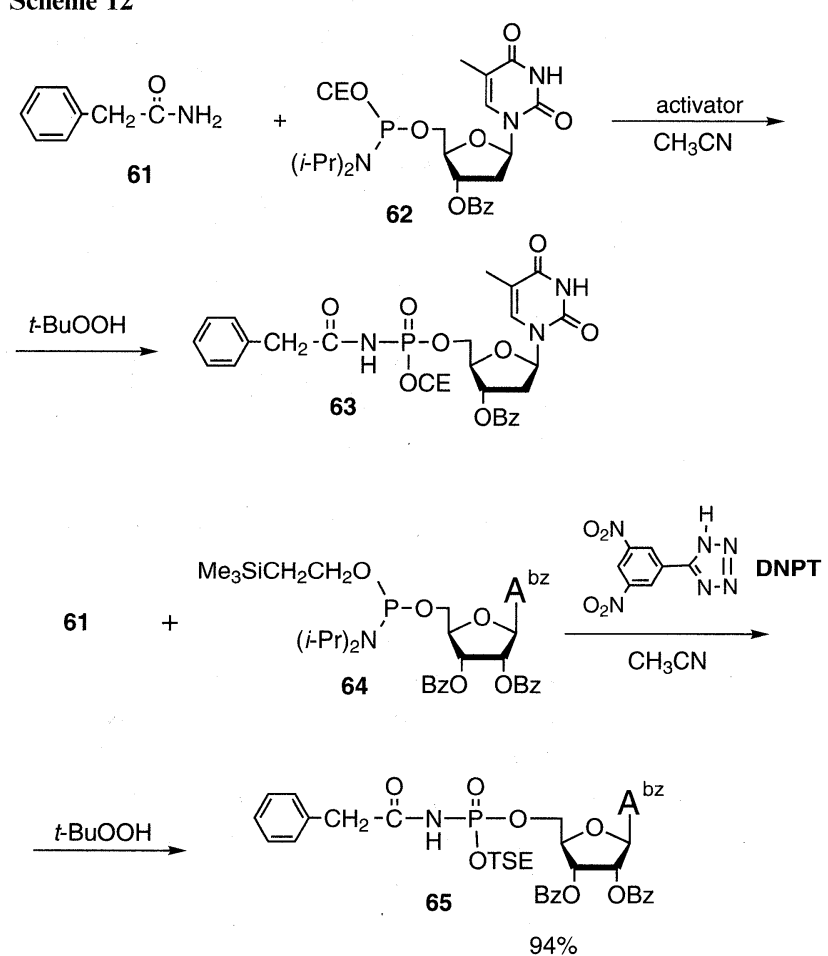

Table 3. $\quad N$-Phosphitylation of phenylacetamide with a thymidine 5 -phosphoramidite derivative in the presence of various acitivators

\begin{tabular}{cccc} 
yctivator & $\begin{array}{c}\text { yield of } 63 \\
\%\end{array}$ & activator & $\begin{array}{c}\text { yield of } 63 \\
\%\end{array}$ \\
\hline & 17 & &
\end{tabular}

the presence of DNPT to give the products 67 , as shown in Scheme 13. These results are summarized in Table 4.

In situ treatment of the initial coupling products 67 with TBAF gave the dissociated products 68 . Full deprotection of 68 with ammonia gave the final products 69. These compounds were found to have weak inhibitory activity of the
Scheme 13

$$
\begin{aligned}
& \text { Base-labile }
\end{aligned}
$$

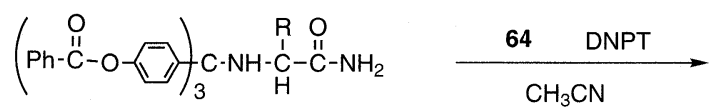

$$
\begin{aligned}
& 66
\end{aligned}
$$

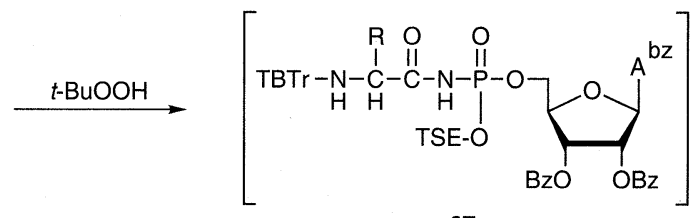

$$
\begin{aligned}
& 67
\end{aligned}
$$

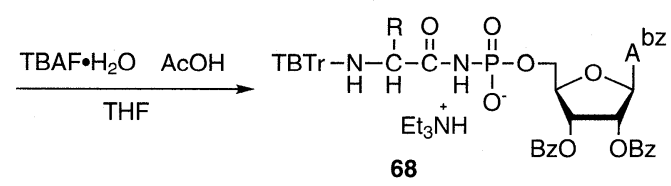

$$
\begin{aligned}
& \underset{\text { dioxane }}{\text { conc. } \mathrm{NH}_{3}} \rightarrow
\end{aligned}
$$

Table 4. Coupling reaction of $\mathbf{6 4}$ with $\mathbf{6 6}$ in the presence of DNPT and deprotection of the resulting products

\begin{tabular}{lcccc}
\hline amino acid & $\begin{array}{c}\text { yield of 68 } \\
\%\end{array}$ & $\begin{array}{c}\text { 31 P NMR } \\
\text { ppm }\end{array}$ & $\begin{array}{c}\text { yield of 69 } \\
\%\end{array}$ & $\begin{array}{c}{ }^{31} \text { P NMR } \\
\text { ppm }\end{array}$ \\
\hline L-Phe & 77 & -7.10 & 55 & -5.37 \\
L-Ile & 57 & -7.05 & 48 & -5.26 \\
L-Met & 62 & -7.28 & 73 & -5.36 \\
L-Val & 83 & -7.05 & 77 & -5.21 \\
L-Tyr & 60 & -7.36 & 55 & -5.25 \\
D-Tyr & 66 & -7.37 & 35 & -5.27 \\
L-Pro & 76 & -7.46 & 65 & -5.26 \\
\hline
\end{tabular}

growth of KB cells, as shown in Table 5.

\subsection{Biological Properties of Phosmidosine}

In 1991, Isono and his coworkers discovered phosmidosine as a new type of antifungal antibiotic. ${ }^{12}$ Later, its structure was definitely determined by mass and NMR spectroscopy. ${ }^{13}$ They described the detailed mechanism of the action of phosmidosine showing that phosmidosine inhibits the expression of cyclin D1 synchronized with that of cyclin-dependent 
kinases so that the hyperphosphorylation of retinoblastoma (RB) protein is inhibited. ${ }^{48}$ Recently, Osada reported an interesting finding that phosmidosine suppresses S-phase entry and arrests cell cycle progression at the G1 phase in human lung fibroblast WI-38cells. ${ }^{49}$

Table 5. Inhibitory effects of $N$-aminoacyl adenylate analogs 69 on the growth of KB cells (MTT method)

\begin{tabular}{ccc}
\hline amino acid & $100 \mu \mathrm{g} / \mathrm{ml}$ & $10 \mu \mathrm{g} / \mathrm{ml}$ \\
\hline L-Phe & $75 \%$ & $6 \%$ \\
L-Hle & $11 \%$ & $4 \%$ \\
L-Met & $52 \%$ & $28 \%$ \\
L-Val & $63 \%$ & $26 \%$ \\
L-Tyr & $30 \%$ & $11 \%$ \\
D-Tyr & $52 \%$ & $1 \%$ \\
L-Pro & $62 \%$ & $20 \%$ \\
\hline
\end{tabular}

The demethylated derivative of phosmidosine, phosmidosine B (77), was also isolated from fermentation broth of Streptomyces $s p$. strain RK-16 along with phosmidosine. ${ }^{12,49}$ Confusion over the nomenclature of this demethylated species arose from the inconsistency between the earlier paper ${ }^{49}$ and the later patent. ${ }^{50}$ Initially, we used the name phosmidosine A as reported in the latter but later followed that first reported by Osada. In this review we adoped the name of phosmidosine $\mathrm{B}$ as the demethylated species of phosmidosine. Phosmidosine B also exhibited a similar but weaker inhibitory activity against the cell cycle progression and morphological reversion activity on $s r c^{\text {ts }}-\mathrm{NRK}$ cells.

\subsection{Synthesis of Phosmidosine B (77) ${ }^{51}$}

A simple starting material for the synthesis of phosmidosine $\mathrm{B}(77)$ is $6-\mathrm{N}$-acetyl-2', $3^{\prime}-\mathrm{O}$-benzoyl-8-oxoadenosine 71. This compound was synthesized from commercially available 8-bromoadenosine $\mathbf{7 0}$ via a 6-step reaction, as shown in Scheme 14. As described in the synthesis of aa-AMP analogues, a similar 5 -phosphoramidite derivative $\mathbf{7 2}$ underwent facile coupling with $N$-TBTr prolinamide derivative 73 to

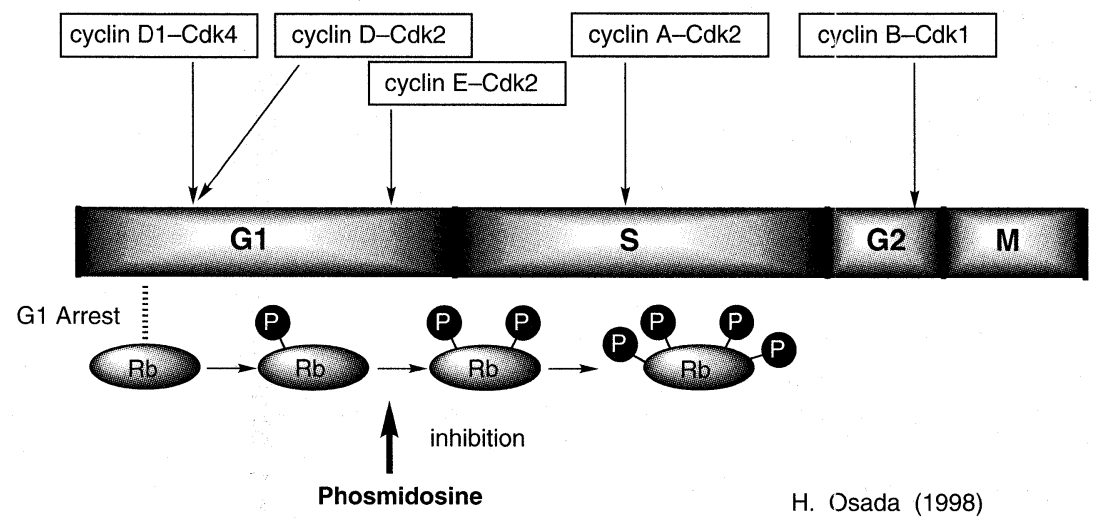

Figure 3. Inhibition of phosphorylation of $\mathrm{Rb}$ proteins by phosmidosine.

Scheme 14

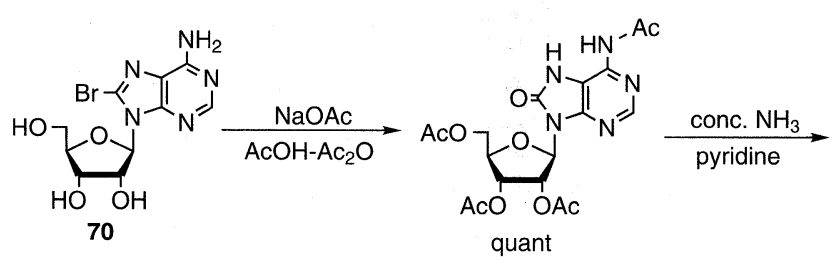

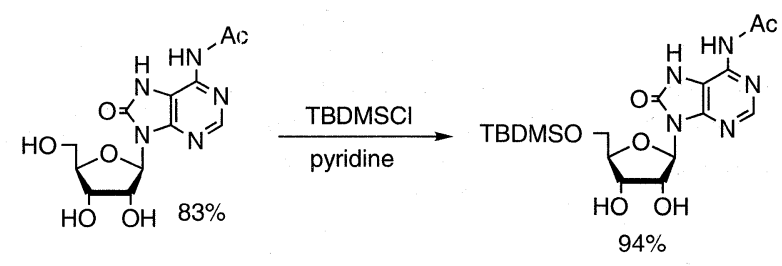
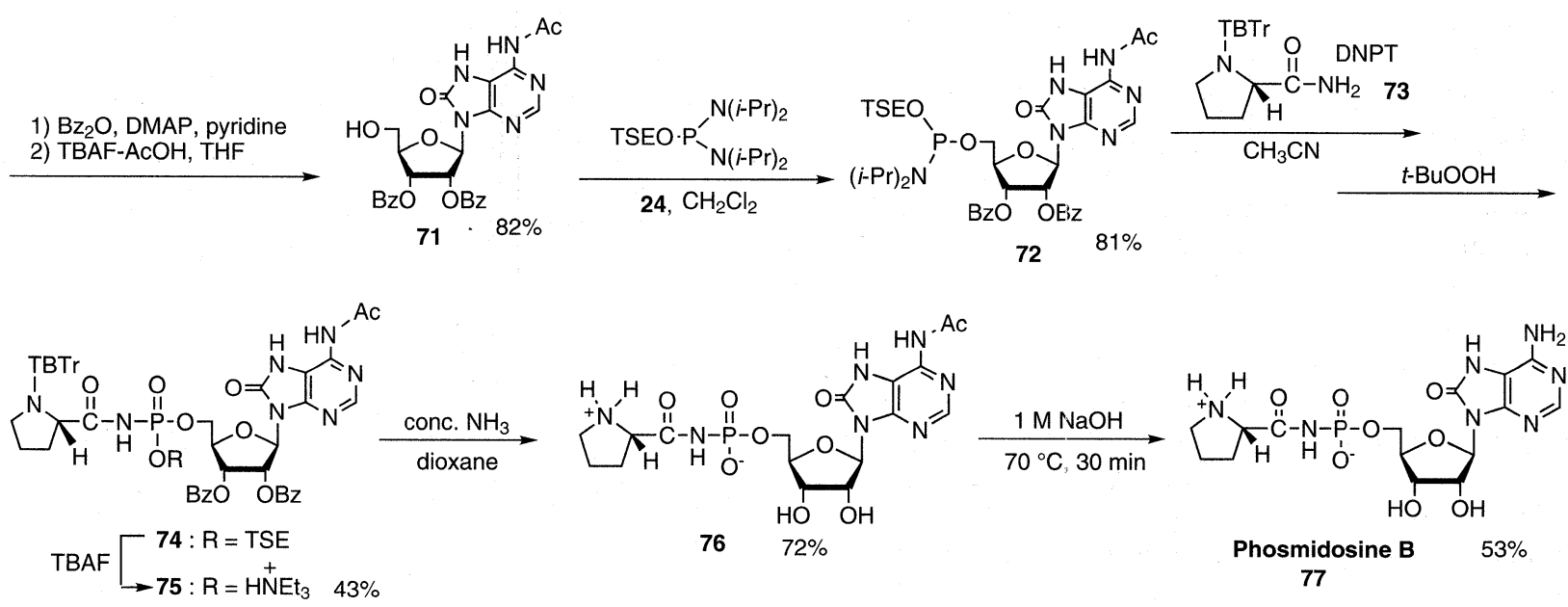

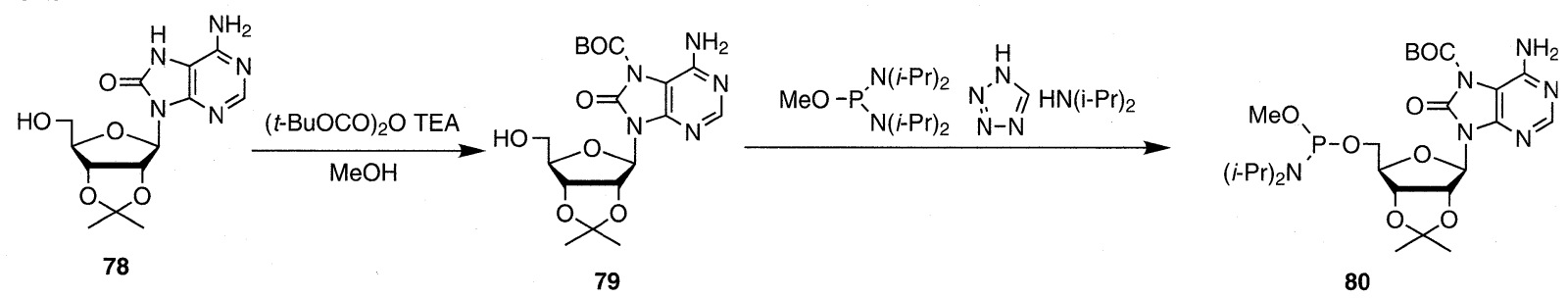

79

80

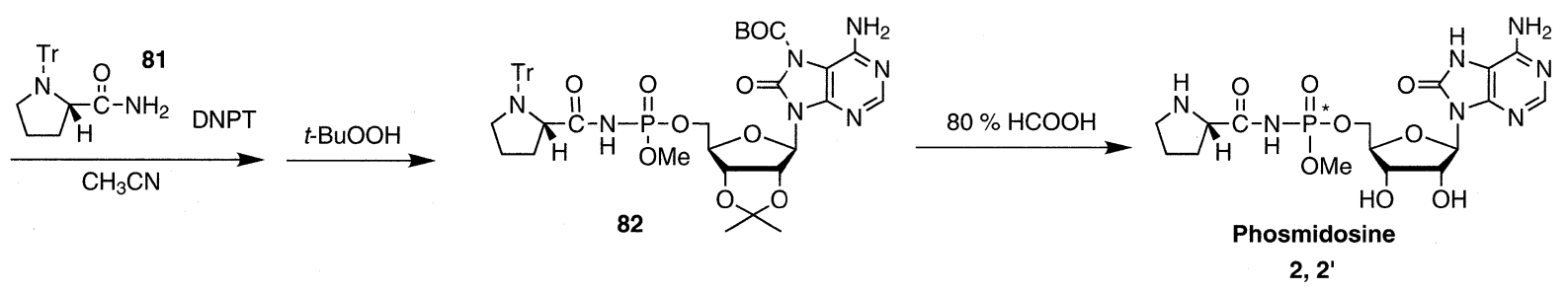

give the fully protected $N$-acyl phosphoramidate derivative 74 which in turn was partially hydrolyzed to give the phosphomonoester 75. Mild treatment of $\mathbf{7 5}$ with ammonia gave the $N$-acetylated phosmidosine B derivative 76. Further treatment of 76 with $1 \mathrm{M} \mathrm{NaOH}$ gave phosmidosine B (77).

\subsection{Synthesis of Phosmidosine (2)}

The methyl group of phosmidosine was very labile under basic conditions. Therefore, at the final stage, the use of baselabile protecting groups should be avoided. Among several protecting groups removable under acidic conditions, the tert-butoxycarbonyl (Boc) group was found to meet the requirement of our synthetic plan. Reaction of the $2^{\prime}, 3^{\prime}-O_{-}$ isopropylidene-8-oxoadenosine derivative 78 with 2 equiv of di-tert-butyl dicarbonate in the presence of triethylamine gave highly selectively a $7-N$-tert-butoxycarbonylated derivative 79. The $5^{\prime}-O$-phosphitylation of 79 proceeded regioselectively to give the $5^{\prime}-O$-phosphoramidite derivative $\mathbf{8 0}$ in $70 \%$ yield, and no product such as phosphitylation of the 6amino group was observed. The coupling reaction of $\mathbf{8 0}$ with the $N$-tritylprolinamide derivative $\mathbf{8 1}$ was carried out in the presence of DNPT to afford the product $\mathbf{8 2}$ in $70 \%$ yield as a diastereomeric mixture. The fully protected product $\mathbf{8 2}$ was treated with $80 \%$ formic acid to give a mixture of the desired natural product phosmidosine $\mathbf{2}$ (slow-eluted product in reverse-phase HPLC) and its diastereomer 2' (fast-eluted product) in $27 \%$ yield.

The ${ }^{13} \mathrm{C}$ NMR data of phosmidosine 2 reported previously are in good agreement with those of the slow-eluted product in reverse-phase HPLC.

\subsection{Anti-Cancer Activity of Phosmidosine and Related Compounds $^{51}$}

Table 4 represents the growth inhibitory activity of phosmidosine B 77 and its $N$-acetyl derivative in various tumor cells. Phosmidosine B 77 and its $N$-acetylated derivative 76 showed the apparent growth inhibitory activities toward the tumor cell lines. ${ }^{51}$ These phosmidosine B derivatives showed higher inhibitory activities than the aminoacyl-adenylate analogues. Therefore, it is strongly suggested that the imidazole ring of the 8-oxoadenosine moiety is very important for the specific recognition. In general, anti-tumor agents, such as CDDP, showed the selective inhibitory activity corresponding to the genotype of the p53 mutant. However, these phosmidosine derivatives did not show only dependence on the
Table 6. The growth inhibitory activities of phosmidosine B 77 and its $N$-acetyl derivative $\mathbf{7 6}$ against various human cancer cells

\begin{tabular}{cccccc}
\hline \multirow{2}{*}{ cell line } & origin & p53 & \multicolumn{3}{c}{$I_{50}(\mu \mathrm{M})$} \\
\cline { 5 - 6 } & & phenotype & 77 & 76 & CDDP \\
\hline KB & Larynx & WT & 190.0 & 180.0 & 0.90 \\
MKN-28 & Stomach & mutant & 130.0 & 128.0 & 3.68 \\
MKN-45 & Stomach & WT & 19.0 & 24.5 & 0.68 \\
KATO III & Stomach & complete & 28.0 & 29.0 & 2.50 \\
& & deletion & & & \\
NUGC-3 & Stomach & mutant & 17.0 & 17.0 & 1.10 \\
NUGC-4 & Stomach & WT & 8.8 & 15.0 & 0.65 \\
SW-48 & Colon & WT & 65.0 & NT & 0.86 \\
LS174T & Colon & WT & 14.8 & NT & 0.64 \\
SW-480 & Colon & mutant & 25.0 & NT & 2.00 \\
HT-29 & Colon & mutant & 24.0 & NT & 6.00 \\
SBC-3 & Lung & WT & 98.0 & NT & 0.68 \\
PC-9 & Lung & mutant & 10.8 & NT & 2.50 \\
\hline NT:
\end{tabular}

NT: not tested

p53 phenotypes in their inhibitory activities.

It also seems to us that the methyl ester of the $N$-acyl phosphoramidate linkage is an important structural determinant for expression of the inhibitory activity of phosmidosine 2. It was expected that there was a difference in the growth inhibitory activity between phosmidosine $\mathbf{2}$ and its diastereomer 2'. However, it turned out that both compounds have

Table 7. The antitumor activities of phosmidosine and it stereoisomer

\begin{tabular}{|c|c|c|c|c|}
\hline \multirow{2}{*}{ cel line } & \multirow{2}{*}{ origin } & \multicolumn{2}{|c|}{ phosmidosine } & \multirow[b]{2}{*}{ phosmidosine } \\
\hline & & fast & slow & \\
\hline $\mathrm{KB}$ & Larynx & 3.2 & 3.6 & 60 \\
\hline KATO-III & Stomach & 2.6 & 1.9 & 20 \\
\hline MKN-28 & & 9.6 & 8.5 & $>100$ \\
\hline MKN-45 & & 2.9 & 2.5 & 23 \\
\hline
\end{tabular}


similar anti-tumor activities, as shown in Table 5. Phosmidosine 2 and its diastereomer $\mathbf{2}^{\prime}$ showed approximately 10 times stronger anti-tumor activities than phosmidosine $\mathrm{B}(\mathbf{7 7})$, as shown in Tables 6 and 7. This non-ionic phosphoramidate moiety is favorable for the activity of phosmidosine. Moreover, inhibitory activities of both $\mathbf{2}$ and $\mathbf{2}^{\prime}$ were essentially independent of the p53 genotype of the tumor cells, as in the case of phosmidosine $\mathrm{B}^{51}$

Acknowledgement We would like to thank Mr. Terukazu Yanagi and Mr. Norio Asai as our coworkers for their energetic and hard work in our lab. This work was supported by a Grant from "Research for the Future" Program of the Japan Society for the Promotion of Science (JSPS-RFTF97I00301) and a Grant-in-Aid for Scientific Research from the Ministry of Education, Culture, Sports, Science and Technology, Japan.

\section{References and Notes}

1) Corbridge, D. E. C. In Phosphorus 2000 Chemistry, Biochemistry \& Technology, Elsevier, Amsterdam (2000) pp 751-924.

2) Cramer, F.; Vallmar, A. Chem. Ber. 1959, 92, 392.

3) (a) Meyerhof, O.; Lohmanana, K. Biochem. Z. 1928, 196, 22. (b) Ennor, A. H.: Morrison, J. F; Rosenberg, H. Biochem. J. 1956, 62, 358. (c) Cramer, F.; Scheiffele, E.; Vollmar, A. Chem. Ber. $1962,95,1670$.

4) Suda, H.; Aoyagi, T.; Takeuchi, T.; Umezawa, H. J. Antibiot. 1973, 26, 621 .

5) (a) Kerr, A.; Htay, H. Physiol. Plant Pathol. 1974, 4, 37. (b) Murphy, P. J.; Roberts, W. P. J. Gen. Microbiol. 1979, 114, 207. (c) Holmes, B.; Roberts, W. P. J. Appl. Bacteriol. 1981, 50, 443.

6) New, P. B.; Kerr, A. J. Appl. Bacteriol. 1972, 35, 279.

7) Lopez, M. M.; Gorris, M. T.; Salcedo, C. I.; Montojo, A. M.; Miro, M. Appl. Environ. Microbiol. 1989, 55, 741.

8) (a) Jones, D. A.; Ryder, M. H.; Clare, B. G.; Farrand, S. K.; Kerr, A. Mol. Gen. Genet. 1988, 212, 207. (b) Webster, J.; Thomson, J. Mol. Gen. Genet. 1988, 214, 142.

9) Kerr, A.; Tate, M. E. Microbiol. Sci. 1984, $1,1$.

10) (a) Roberts, W. P.; Tate, M. E.; Kerr, A. Nature 1977, 265, 379. (b) Tate, M. E.; Roberts, W. P.; Kerr, A. Nature 1979, 280, 697.

11) (a) Hatano, M.; Marumoto, R.; Hashimoto, Y. Anim. Plant Microb. Toxins, Proc. Int. Symp., 4th 1974, 2, 145. (b) Hatano, M.; Hashimoto, Y. Toxicon 1974, 12, 231.

12) Uramoto, M.; Kim, C. J.; Shin-ya, K.; Kusakabe, H.; Isono, K.; Phillips, D. R.; McCloskey, J. A. J. Antibiot. 1991, 44, 375.

13) Phillips, D. R.; Uramoto, M.; Isono, K.; McCloskey, J. A. J. Org. Chem. 1993, 58, 854 .

14) The paper concerning the total synthesis of agrocin 84 was presented in International Chemical Congress of Pacific Basin Societies PACIFICHEM 2000, Honolulu, Hawaii.

15) Mizuno, Y.; Itoh. T.; Tagawa, H. Ind. \& Chem. 1965, 1498.

16) Sasaki, T.; Mizuno, Y. Chem. Pharm. Bull. 1967, 15, 894.

17) Michelson, A. M.; Todd, A. R. J. Chem. Soc. 1953, 34.

18) Gryaznov, S. M.; Letsinger, R. L. J. Am. Chem. Soc. 1991, 113, 5876.

19) Gryaznov, S. M.; Letsinger, R. L. Nucleic Acids Res. 1992, 20, 1879.

20) Uchiyama, M.; Aso, Y.; Noyori, R.; Hayakawa, Y. J. Org. Chem. 1993, 58,373

21) (a) Letsinger, R. L.; Mungall, W. S. J. Org. Chem. 1970, 35, 3800. (b) Letsinger, R. L.; Hapke, B.; Petersen, G. R.; Dumas, L. B. Nucleic Acids Res. 1976, 3, 1043. (c) Hata, T.; Yamamoto, I.; Sekine, M. Chem. Lett. 1976, 601. (d) Bannwarth, W. Helv. Chem. Acta 1988, 71, 1517. (e) Gryaznov, S. M.; Azhaev, A. V. Bioorg. Khim. 1989, 15, 994. (f) Mag, M.; Engels, J. W. Nucleic Acids Res. 1989, 17, 5973. (g) Gryaznov, S. M.; Letsinger, R. L. Nucleic Acids Res. 1992, 20, 3403. (h) Gryaznov, S. M.; Letsinger,
R. L. Tetrahedron Lett. 1992, 33, 4127. (i) Mag, M.; Schmidt, R.; Engels, J. W. Tetrahedron Lett. 1992, 33, 7319. (j) Gryaznov, S. M.; Letsinger, R. L. Tetrahedron Lett. 1993, 34, 1261. (k) Gryaznov, S. M.; Letsinger, R. L. Nucleic Acids Res. 1993, 21 , 1403.

22) Wada, T.; Moriguchi, T.; Sekine, M. J. Am. Chem. Soc. 1994, 116, 9901.

23) Tsuruoka, H.; Shohda, K.; Wada, T.; Sekine, M. Tetrahedron Lett. 1999, 40, 8411.

24) Unpublished results.

25) (a) Ryder, M. H.; Slota, J. E.; Scarim, A.; Farrand, S. K. J Bacteriol. 1987, 169, 4184. (b) Law, I. J.; Strijdom, B. W. Arch. Macrobiol. 1989, 152, 463.

26) (a) Van Zyl, F. G. H.; Strijdom, B. W.; Staphorst, J. L. Appl. Environ. Microbiol. 1986, 52, 234. (b) Cooksey, D. A. Plasmid, 1986, 16, 222. (c) Hayman, G. T.; Farrand, S. K. J. Bacteriol. 1988, 170, 1759. (d) Hayman, G. T.; Farrand, S. K. Mol. Gen. Genet. 1990, 223, 465.

27) Murphy, P. J.; Tate, M. E.; Kerr, A. Eur. J. Biochem. 1981, 115, 539.

28) Thompson, R. R.; Hamilton, R. H.; Pootjes, C. F. Antimicrob. Agents Chemother. 1979, 16, 293.

29) Wada, T.; Moriguchi, T.; Sekine, M. J. Org. Chem. 1996, 61, 9223.

30) Vinayak, R.; Hansske, F.; Robins, M. J. J. Heterocyclic Chem. 1993, 30, 1181.

31) (a) Filippov,D).; Timmers, C. M.; vander Marel, G. A.; van Boom, J. H. Nucleosides Nucleotides 1997, 16, 1403. (b) Filippov, D.; Timmers, C. M.; Roerdink, A. R.; van der Marel, G. A.; van Boom, J. H. Tetrahedron Lett. 1998, 39, 4891.

32) Bunton, C. A.; Humeres, E. J. Org. Chem. 1969, 34, 572.

33) Wada, T.; Sekine, M. Tetrahedron Lett. 1994, 35, 757.

34) (a) Murray, D. H.; Prokop, J. J. Pharm. Sci. 1965, 54, 1468. (b) Martinez, A. P.; Lee, W. W.; Goodman, L. J. Org. Chem. 1966, 31, 3263. (c) Hansske, F.; Robins, M. J. J. Am. Chem. Soc. 1983, 105, 6736. (d) Nyilas, A.; Chattopadhyaya, J. Synthesis 1986, 196. (e) Kawana, M.; Kuzuhara, H. Tetrahedron Lett. 1987, 28 , 4075. (f) Herclewijn, P.; Balzarini, J.; Pauwels, R.; Janssen, G.; Van Aerschot, A.; De Clercq, E. Nucleosides and Nucleotides 1989, 8, 1231. (g) Herdewijn, P. Tetrahedron 1989, 45, 6563.

35) Kawana, M.; Emoto, S. Bull. Chem. Soc. Jpn. 1980, 53, 222.

36) Kamimura, T.; Tsuchiya, M.; Urakami, K.; Koura, K.; Sekine, M.; Shinozaki, K.; Miura, K. and Hata, T. J. Am. Chem. Soc. 1984, 106, 4552.

37) Robles, J.; Pedroso, E.; Grandas, A. J. Org. Chem. 1995, 60, 856.

38) (a) Moriguchi, T. Yanagi, T.; Kunimori, M.; Wada, T.; Sekine, M. J. Org. Chem. 2000, 65, 8229. (b) Moriguchi, T. Yanagi, T.; Wada, T.; Sekine, M. Tetrahedron Lett. 1998, 39, 3727.

39) Watson, J. D.; Hopkins, N. H.; Roberts, J. W.; Steitz, J. A.; Weiner, A. M. Molecular Biology of the Gene; Benjamin/Cummings Pub. Co. Inc.: Melno Park; 1987; Vol. 1.

40) Arnez, J. G.; Harris, D. C.; Mitschler, A.; Rees, B.; Francklyn, C. S.; Moras, D. EMBO J. 1995, 14, 4143.

41) Cassio, D. Biochemistry, 1967, 6, 827.

42) Biryukov, A. I. FEBS Lett. 1978, 91, 249.

43) Ueda, H. Biochim. Biophys. Acta 1991, 1080, 126

44) Biou, V Science 1994, 263, 1404.

45) Reese, C. B.; Zhuo, Z. P. J. Chem. Soc. Perkin. Trans. 1. 1993, 2291.

46) Beaucage, S. L.; Caruthers, M. H. Tetrahedron Lett. 1981, 22, 1859.

47) (a) Sekine, M. Hata, T. J. Org. Chem. 1983, 48, 3011. (b) Sekine, M., Iwase, R.; Masuda, N.; Hata, T. Bull. Chem. Soc. Jpn., 1988, 61, 1660. (c) Iwase, R.; Sekine, M.; Hata, T.; Miura, K. Tetrahedron Lett. 1988, 29, 2969.

48) Kakeya, H.; Onose, R.; Liu, P.C.-C.; Onozawa, C.; Matsumura, F.; Osada, H. Cancer Res. 1998, 58, 704.

49) Matsuura, N.: Onose, R.; Osada, H. J. Antibiot. 1996, 49, 361.

50) Osada, H.; Matsuura, N. Jpn patent 1997, 09-0030091.

51) Moriguchi, T.; Asai, N.; Wada, T.; Seio, K.; Sasaki, T.; Sekine, M. Tetrahedron Lett. 2000, 41, 5881. 


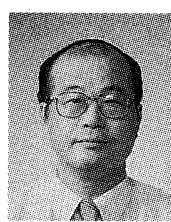

Mitsuo Sekine is a Professor of the Department of Life Science at Tokyo Institute of Technology. He was born in Shirakawa in 1949 and received his B. Sc. (1972) and D. Sc. (1978) from Tokyo Institute of Technology under the supervision of the late Professor Tsujiaki Hata. He became a Research Associate of Professor HataÅås lab in 1978 and was promoted to Lecturer in the Department of Chemical Environmental Engineering in 1988. He moved to the Department of Life Science as Associate Professor in 1989 and became Professor in 1999 . He received the Chemical Society of Japan Award for Young Chemists in 1982 and the Tejima Memorial Award for Encouragement of Research in 1986. His research interests involve innovative new strategies for the DNA/RNA chemical synthesis, the design and synthesis of artificially functionalized oligonucleotides, and development of new anti-tumor and anti-virus drugs based on nucleic acid chemistry.

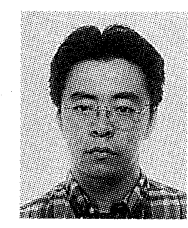

Tomohisa Moriguchi is a Research Associate at Gunma University. He was born in Hokkaido in 1969 and received his $\mathrm{Ph}$. Degree (1997) from Tokyo Institute of Technology. In 1997, he became a Research Associate of the "Research for the Future" Program of JSPS. He was appointed a Research Associate of the Department of Chemistry at Gunma University in 2001. His current research interests include development of nucleic acid analogues containing novel functionality.
Takeshi Wada is an Associate Professor at The University of Tokyo. He was born in Kamakura in 1961 and received his B. Sc. (1986) from Science University of Tokyo and Ph. D. (1991) from Tokyo Institute of Technology. He joined the Department of Life Science in Tokyo Institute of Technology in 1991 as a Research Associate. In 1999, he was promoted to Associate Professor of Graduate School of Frontier Sciences in The University of Tokyo. His current research interests include organic chemistry of nucleic acids, organophosphorus chemistry, and supramolecular chemistry.

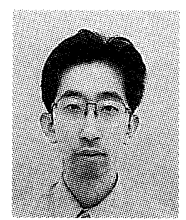

Kohji Seio is a Research Associate at Tokyo Institute of Technology. He was born in Oita Prefecture in 1968 and received his B. Sc. (1991) and Ph. D (1996) from Tokyo Institute of Technology. He joined Yoshitomi Pharmaceutical Industry Co., Ltd. as a medicinal chemist in 1996 and moved to Tokyo Institute of Technology in 1999. His research interests are in the area of bioorganic chemistry, especially, of nucleic acids and related compounds. 